\title{
REAL SUBSUMPTION OF LABOR UNDER CAPITAL AND DISPOSSESSION PRACTICES. QUESTIONS TO MICHAEL HARDT
}

\author{
PIOTR JUSKOWIAK
}

Re-reading Michael Hardt and Antonio Negri's trilogy confirms a reader's conviction that she is dealing with one of the most ambitious philosophical attempts to re-define our contemporaneity ${ }^{1}$. The shape of the latter, as Negri writes, has changed to the extent that it could not be described again using the prefix post- (Negri 2011) and our perception of this fact is strengthened by the experience of several crucial turns and transformations. This list includes such changes as transition from Fordism to post-Fordism, from industrial to cognitive capitalism, from material to biopolitical production, from imperialism to Empire and, finally, from city to metropolis. Each of them undoubtedly puts pressure on different elements of the overall transformation, all of them remain at the same time in a close connection with the transition already announced by Marx - the movement from formal to real subsumption of labor under capital (Marx 2013). Although in the era of abrupt geographical expansion of neoliberalization this process seems to define lives of billions of people (making them ultimately identical with broadly understood production process) this transition is burdened with numerous paradoxes and unresolved contradictions (Read 2003) which questions the total

\footnotetext{
1 Which is, according to Michel Foucault and Michael Hardt, the most important, transformative task of the theory itself (Foucault 2007; Hardt 2011).
} 
character of subsumption claimed by post-operaist theorists. Below I would like to briefly examine one of these contradictions, referring to dispossession practices taken as a dominant form of the capturing of value in medium and large cities.

Taking the problem of paradoxes inherent in the Marxist approach to subsumption, it is worth stopping for a moment to sketch the role of this concept in the Marxian work. Many of the problems encountered by the interpreters of Results of Direct Production Process come as a result of its sketchy nature as well as abstracting the mentioned conceptual transition from the phenomena of conflict and antagonism (Read 2003, 111). Let us focus on the latter. Thanks to such authors as Hardt, Negri and Jason Read (in another context also Michael Lebowitz or Harry Cleaver), we know beyond any doubt that the transition from formal to real subsumption has not only a quantitative nature (due to necessary conversion from absolute to relative surplus value), but also that a qualitative transformation of both the system and workers' subjectivity result as much from technological transformation of labor process as from struggles of working class with the capital. Reading Results of Direct Production Process it is hard, however, not to get an impression that these struggles will steadily lose their importance due to sense of necessity and irreversibility accompanying the already fully "socialized" transformation of the capitalist mode of production. Even if we agree with the argument that such a situation is to a greater extent the effect of capitalist mystification than the actual extinction of the class war, there are many indications that the same appearance as a necessary component and dispositif of real subsumption (e.g. in the form of a modernization or aesthetisation discourse) is increasingly successful at co-opting new silent allies of the system. Writing this I have in mind, for instance, the theses of Luc Boltanski and Eve Chiapello on the justifying power of capitalism, which strengthens its position constantly by responding to subsequent waves of social and artistic critique (Boltanski and Chiapello 2007). I refer here also to the issue of the neutralizing features of consumption and the growing needs of workers as a function of capital's growth (Lebowitz $2003,38)$. As one of my fields of interest are radical urban studies I try to translate this problem on the issue of the increasingly popular policy of Western cities (as well as an increasing number of non-Western cities, see Davis 2007) - the common combination of neoliberal strategies of urban entrepreneurialism (Harvey 1989) with the deep interest in social creativity (Peck 2010; Scott 2009). To what extent does the capturing of the latter by the capitalist mode of production mean disarming resistance through the gradual satisfaction of aesthetic needs and ambitions of the middle class, rather than equipping the global precariat with the tool of creative sabotage of urban rent (Pasquinelli 2008)?

For my second question I would like to go back to the point mentioned above, namely the supposed necessity and totality of real subsumption. Although your texts focus on tendentious character of that process, which should impregnate them to the charge of historicism, western ethnocentrism or (referring again to urban studies) metropolitan bias, you 
happen to write also about the "fully realized real subsumption of society under capital" (Negri 2013, XII). On the other hand, you admit that what distinguishes the current phase of capitalist expansion is the return movement - from real to formal subsumption. It "corresponds, in certain respects, to the recent reappearance of many antiquated, parasitical forms of capitalist appropriation" (Hardt and Negri 2009, 230). The coexistence and varied frequency of different models of subsumption would serve here as an evidence of nonlinear, contextual and "variegated" character (Brenner, Peck, Theodore 2010) of site-specific economic restructuring strategies. However, one cannot but agree with such authors as David Harvey, Massimo De Angelis or Sandro Mezzadra (De Angelis 2001; Harvey 2003; Mezzadra 2008), who insist on the urgent need to reinterpret and update the concept of primitive accumulation (e.g. in the form of accumulation by dispossession), which confirms the growing importance of worldwide process of proletarianization. If the separation of producers from their means of production and subsistence takes on new, more profitable and at the same time fully mystified forms (e.g. clearing slums for new investments, gentrification or, more broadly, extraction of urban rent, privatization of culture), does capital still have to strive for the generalization of real subsumption which is based on the opposite phenomenon, namely socialized work? Do returns to -- or consciously staying at the phase of formal subsumption -- lead us to another qualitative change of the mode of production? If so, how would it refer to communist project and prevalent position that material conditions for its implementation will not be created until the phase of real subsumption?

My last question is inspired by the recent book written by Sandro Mezzadra and Brett Neilson (Mezzadra and Neilson 2013) as well as some problems I'm having with your concept of space, geography or metropolis (without reducing my admiration for thought-provoking work that addresses these questions and provides an interesting exchange with such authors as Saskia Sassen, Davis or Harvey). The assertion of fully realized real subsumption may suggest that we are returning to the universalizing and homogenizing thesis on smooth space of Empire, which met with serious criticism after publication of your second joint work (Hardt and Negri 2000). If so, we would deal here with a metropolitan bias, which is so typical for contemporary urban Marxism and may contribute to further exclusion not only of villages, but also small and medium-sized cities from such analyses. Meanwhile, as Mezzadra and Neilson claim, capital never ceases to produce its constitutive outsides, constantly folding, redefining and innovatively dividing its space (both within a single, specific location, and on the basis of spatial relations between different places). Combining the intensive and extensive strategies of expansion, it continuously uses the movement of formal subsumption (Mezzadra and Neilson 2013, 72). I would like to ask in this context about role of borders and geographical differences in your analysis of subsumption movements? Can we say that heterogeneity of geographies of production weakens your thesis about growing isomorphism of contemporary capitalism as well as its political counterpart, namely the parallelism of struggles? 


\section{References}

Boltanski, Luc and Eve Chiapello. 2007. The New Spirit of Capitalism, translated by Gregory Elliott. Verso: London-New York.

Brenner, Neil, Jamie Peck and Nik Theodore. 2010. "Variegated Neoliberalization. Geographies, Modalities, Pathways.” Global Networks 10.2.

Davis, Mike. 2007. Planet of Slums. Verso: London-New York.

De Angelis, Massimo. 2001. "Marx and Primitive Accumulation. The Continuous Character of Capital's 'Enclosures'." The Commoner 2.

Foucault, Michel. 2007. "What Is Critique." In The Politics of Truth, edited by Sylvère Lotringer. Semiotext(e): New York.

Hardt, Michael. 2011. "The Militancy of Theory." The South Atlantic Quaterly 110.1.

Hardt, Michael and Antonio Negri. 2000. Empire. Harvard University Press: Cambridge, MALondon.

Hardt, Michael and Antonio Negri. 2004. Multitude. War and Democracy in the Age of Empire. Penguin Books: New York.

Hardt, Michael and Antonio Negri. 2009. Commonwealth. Belknap Press: New York.

Harvey, David. 1989. "From Managerialism to Entrepreneurialism. The Transformation of Urban Governance in Late Capitalism." Geografiska Annaler: Series B, Human Geography 71.1.

Harvey, David. 2003. The New Imperialism. Oxford University Press: Oxford.

Marx, Karl. 2013. Kapitat 1.1. Rezultaty beapośredniego procesu produkcji (Results of Direct Production Process), translated by Mikołaj Ratajczak. Wydawnictwo Naukowe PWN: Warszawa.

Mezzadra, Sandro. 2008. "La cosiddetta Accumulazione Originaria." In Libera Università Metropolitana. Lessico Marxiano. 12 concetti per ripensare il presente. Manifestolibri: Roma.

Mezzadra, Sandro and Brett Neilson. 2013. Border as Method, or, the Multiplication of Labor. Duke University Press: Durham-London.

Negri, Antonio. 2011. "In Search of the Commonwealth", translated by Arianna Bove. http: //eipcp.net/transversal/0811/negri/en

Negri, Antonio. 2013. Przedmowa do polskiego wydania (A Preface to Polish Edition), translated by Sławomir Królak. In Karl Marx. Kapitał 1.1. Rezultaty beappośredniego procesu produkcïi Results of Immediate Production Process), translated by Mikołaj Ratajczak. Wydawnictwo Naukowe PWN: Warszawa.

Pasquinelli, Matteo. 2008. Animal Spirits. The Bestiary of the Commons. Nai Publishers: Rotterdam. Peck, Jamie. 2010. Constructions of Neoliberal Reason. Oxford University Press: Oxford.

Read, Jason. 2003. The Micro-Politics of Capital. Marx and Prehistory of the Present. State University of New York: Albany.

Scott, Allan J. 2008. Social Economy of the Metropolis. Cognitive-Cultural Capitalism and the Global Resurgence of Cities. Oxford University Press: Oxford-New York. 
Piotr Juskowiak - is an assistant professor at the Institute of Cultural Studies of Adam Mickiewicz University in Poznań, Poland, editor of peer-reviewed journal Praktyka Teoretyczna/Theoretical Practice and translator. His areas of interest are critical urban studies (especially urban Marxism); political philosophy; urban cultural economy; socio-political aspects of contemporary art; processes of restructuring in post-socialist cities. He is an author of Przestrzenie wspólnoty: Filozofia wspólnotowości w perspektywie badań nad miastem postindustrialnym (Spaces of Community: Philosophy of Commonality in the Context of the Research on Post-Industrial City, Poznań 2015) and co-editor of a collected volume Ekologie (Ecologies, Lódź 2014, together with Aleksandra Jach and Agnieszka Kowalczyk).

\section{ADDRESS:}

Institute of Cultural Studies of Adam Mickiewicz University in Poznań, Poland

Unit of Cultural Urban Studies

ul. Szamarzewskiego 89A

60-568 Poznań

EMAIL: pjusko@amu.edu.pl

CITATION: Juskowiak, Piotr. 2015. "Real Subsumption of Labor Under Capital and Dispossession Practices. Questions to Michael Hardt.” Praktyka Teoretyczna 2(16): 155-159.

DOI: $10.14746 /$ prt.2015.2.8

AUTOR: Piotr Juskowiak

TYTUL: Realna subsumcja pracy pod kapitał i praktyki wywłaszczenia. Pytania do Michaela Hardta 